The University of Maine

DigitalCommons@UMaine

Publications

Senator George J. Mitchell Center for Sustainability

Solutions

6-2014

\title{
Managing the middle ground: forests in the transition zone between cities and remote areas
}

Charles Colgan

University of Southern Maine

Malcolm L. Hunter Jr.

mhunter@maine.edu

Aaron Weiskittel

University of Maine, aaron.weiskittel@maine.edu

Brian McGill

University of Maine, brian.mcgill@maine.edu

Follow this and additional works at: https://digitalcommons.library.umaine.edu/ mitchellcenter_pubs

Part of the Forest Sciences Commons

\section{Repository Citation}

Colgan, C., McGill, B., Hunter, M.L., and Weiskittel, A. 2014. Managing the middle ground: Forests in the transition zone between cities and remote areas. Landscape Ecology 29: 1133-1143.

This Article is brought to you for free and open access by DigitalCommons@UMaine. It has been accepted for inclusion in Publications by an authorized administrator of DigitalCommons@UMaine. For more information, please contact um.library.technical.services@maine.edu. 
Managing the middle ground: forests in the transition zone between cities and remote areas

Charles Colgan, Malcolm L. Hunter, Brian McGill and Aaron Weiskittel

C. Colgan: Muskie School of Public Service, University of Southern Maine, 226 Wishcamper Hall, Portland, ME 04104, USA

M.L. Hunter: Department of Wildlife, Fisheries, and Conservation Biology, University of Maine, 5755 Nutting Hall, Orono, ME 04469, USA

B. McGill: School of Biology and Ecology, University of Maine, 5751 Murray Hall, Orono, ME 04469, USA

A. Weiskettel: School of Forest Resources, University of Maine, 5755 Nutting Hall, Orono, ME 04469, USA 


\begin{abstract}
Introduction

Value of transitional forests

An integrated approach to management

Box 1: Adapting transitional forest management to climate change

Acknowledgements

References

Figures
\end{abstract}




\begin{abstract}
In many parts of the world there are extensive landscapes where forests and people strongly intermingle, notably in the suburbs and exurbs of cities. This landscape of transitional forest generally receives limited attention from policy makers and researchers who tend to be rooted in traditions centered on either urban planning or management of natural resources in rural areas. The transitional forest is on the periphery of both perspectives, but it is a large area that provides numerous important values (biodiversity, ecosystem function, forest products, and amenities) to the people that live in them and their neighboring cities. Here we argue for increased attention to transitional forests, identify major challenges, and suggest changes to planning and management practices needed to ensure that the values of these forests are sustained.
\end{abstract}

Keywords Forests: Ecosystem services Urban planning Natural resources management 


\section{INTRODUCTION}

Forests serve a wide range of socio-economic and ecological functions that vary dramatically along a continuum of human population density (Medley et al. 1995). These functions range from providing key amenities such as shade and recreation opportunities in urban parks to the extraction of various products in remote areas dominated by forests. Forests located in the transition zone at intermediate human densities also have important values, but face a range of critical issues and may require different mixes of management strategies. The existence and importance of these transitional forests has been recognized, particularly in terms of public perceptions (Edwards and Bliss 2003; Shelby et al. 2004), but they have been relatively overlooked in terms of research and management. For example, Martin et al. (2012) indicate a significant bias in the ecological scientific literature in which protected areas receive disproportionately much greater focus relative to their actual extent. Conversely, areas of dense settlement have been understudied, although the field of urban ecology is rapidly growing (Alberti et al. 2003).

Only recently have there even been efforts to name this forest that is a transition between remote and urban forests. Consequently, a variety of terms have emerged, including: exurban forest (Egan and Luloff 2000; Stein et al. 2009), wildland-urban interface forest (Radeloff et al. 2005), intermix use forest, backyard forests, and small-scale forest (Fischer et al. 2010). Suffice it to say that it is probably impossible to craft a specific, universal definition for these forests, and therefore we will use a 
fairly generic term, transitional forests. Regardless, differing definitions of the transitional forest can create contrasting images. For example, maps can show a strong gradient when using two common definitions: (a) forests where the density of households falls between 1 and $100 \mathrm{~km}^{-2}$ and (b) forested lands within census Metropolitan Statistical Areas with the urban cores removed (Stein et al. 2009) (Fig. 1).

Part of the confusion about the transitional forest reflects different perspectives. Foresters looking toward the city from their vantage point see one edge of urbanization as the starting point for their activities, while urbanists looking outward from the core city may see a different edge as their ending point (Fig. 2). For example, foresters tend to focus on regions where the median forest tract is at least 4 ha, while an urbanist might be most interested in forests that are within $1 \mathrm{~h}$ travel from an urban center. Near some cities these zones of interest will overlap to some degree, but elsewhere there may be a gap. However, in all cases this is an area of diminished interest for traditional foresters and urbanists. Indeed, urbanists usually see these transitional forests only as part of the stock of "open space” along with agricultural lands and parks; i.e. it is "forest cover", not a "forest." Yet for many urban area residents, the forest may be an important defining characteristic of the region, especially if the forest protects against exurban sprawl and allows an urban region to seem rural (Theobald 2005). 
The relative lack of attention to transitional forests is important to correct for three key reasons. First, these forests are often in transition in a temporal sense, not just spatially. Specifically, they experience the most rapid ownership turnover and greatest threat of conversion. Second, these forests are often where preservation for amenity reasons competes most directly with interests that would prefer using forests to generate products for human consumption. Finally, forests provide a number of ecosystem services that are costly or impossible to transport in space and therefore provide greatest value in close proximity to humans, particularly when placed in a landscape context (Wu 2008). This paper attempts to provide a framework for discussing these transitional forests, identify some key values and issues, and recommend approaches for effective management.

\section{VALUE OF TRANSITIONAL FORESTS}

To manage transitional forests, it is necessary to understand the different values humans place on these forests. Therefore, we begin with a brief review of four major sources of value and related issues: products, biodiversity, ecosystem functions, and amenities. (See Table 1 for an extraction of key points).

Forest products 
Values

Although located in or near metropolitan regions, many of these forests can still function as significant working forest lands, providing a range of renewable products for society (Wear et al. 1999). These include traditional pulp, firewood, and sawlogs; biomass fuel; food such as maple syrup, mushrooms, nuts, and berries; and medicinal plants. These products can provide a long- term and stable source of income that is less tied to financial markets than other investment options. Increasingly, some landowners value the fact that these products can be provided close to where they are consumed and without industrial-scale practices. The economic returns from selling products can help subsidize other management activities such as ecosystem restoration, forest structure enhancement, recreational trail construction, and forest fire fuel reductions that might otherwise be costprohibitive. Additionally, transitional forests can provide public education or demonstration functions about forest management that are readily accessible to sizable populations.

Issues

The key issue for forest products in transitional forests is the high competition for 
alternative land uses in which forest production is just one value, and often not the highest economic value. Other pressures, particularly from development, can often outweigh and outcompete the use of the forest for products. In addition, there is high variability and uncertainty in current and future avail- ability of forest product markets (Alderman 2013). Another key issue is the large volume of wood products needed to maintain profitability because most primary forest products are relatively low value and there is a significant cost for extraction, particularly as the parcel size decreases (Thorne and Sundquist 2001; Gordon et al. 2004). Also, there are a range of policy restrictions from different government agencies (e.g. local planning boards, state environmental agencies) that regulate how forests can be managed, such as the density of residual trees that need to be left after harvest. This is particularly true because the ecological and amenity values described below may receive heightened scrutiny in places where there are many neighbors (Butler et al. 2010). This often necessitates the expense of hiring individuals with specialized knowledge to develop and execute forest management plans, a significant deterrent for the small woodlot owners who tend to own transitional forests unless there are incentives beyond the market to actively manage stands such as is the case with certain property tax preferences for forest land (e.g. Maine Revenue Services 2013). Finally, an important and key issue with managing for forest products in transitional forest are aesthetic concerns of neighboring landowners (i.e. NIM- BY syndrome). This can often be a difficult issue to address and requires significant planning, education, and notification of planned activities (McWilliam et al. 2014). 
Biodiversity

Values

A striking range of species is present in these forests with only the most sensitive species, such as wide-ranging carnivores, likely to be entirely absent with considerable variation found along the gradient (Gibbs 1998; Godefroid and Koedam 2007). Even these species may live surprisingly close to people if protected from persecution (e.g. wolves in Italy and leopards in India; Athreya et al. 2013). Furthermore, many species find high-quality habitat in the landscapes and reach sizable populations. This is most obviously true of those species that take advantage of resources associated with people (e.g. by eating garbage), and those that prefer the kind of environ- mental conditions humans have historically sought (i.e. fertile soils and a benign climate) (Hansen et al. 2005). In regions dominated by agricultural lands and lawns, remnant forests provide important connectivity for populations of forest species. Even fragmented into forest patches they may still serve as stepping stones for some species (Zipperer et al. 2012; Neuschulz et al. 2013).

Issues 
It is important to know if various species are thriving in these transitional forests or just surviving; i.e. are they sinks or sources for regional populations? There are a number of reasons why particular species may be limited. Most notable is the fragmentation of the forest into patches, isolated in a matrix of other land uses and dissected by roads, thus reducing population connectivity for some species (Tilghman 1987; Degraaf and Healy 1990; Soulé 1991; Lindenmayer and Fischer 2003). Inevitably, a higher density of people can mean more direct exploitation of some species (e.g. hunting game, collecting plants, and capturing wild pets such as turtles), and indirect exploitation through depredations by domestic cats and dogs with resulting variation in species present (Gibbs 1998; Godefroid and Koedam 2007). Invasive species are also more common in these landscapes and they often limit native species through competition, consumption, and disease (Patterson et al. 2000). Contaminants are likely to be more common near farms and homes, both the obvious toxins of pesticides, and more subtle contaminants such as sediment and fertilizer. Forest species are sensitive to forest structure and composition which in turn is driven by forest management. In these landscapes having a diversity of owners often means having diverse conditions because landowners have differing goals and, if they choose to harvest products, they usually do so in different years thus generating some age-class diversity at the landscape scale. However, both relatively old and relatively young forests and their associated species may be uncommon because frequent turnover in ownership may limit the number of forests 
that become very old, and small woodlots are less likely to be harvested thus limiting the number of early successional forests (D’Amato et al. 2010; Butler et al. 2010).

Ecosystem functions

Values

Forests near urban areas are usually a key element in urban water supply and flood control systems (Beattie et al. 2000). While the largest urban areas may have water supplied from distant sites, commonly the urban water source lies near the metro area where forests typically play a key role in providing water filtration and buffering functions. The filtration function is particularly critical where groundwater is the direct source of water for human consumption, but it is also critical for surface waters. In regions where the population density is insufficient to support centralized waste disposal, forested land provides filtration for waste disposal from septic systems. Forests can also play important roles in reducing peak flows by buffering the discharge of intense rain events as well as preventing erosion and ensuing sediment loads. This is particularly important in places where flooding leads to overflows of sewage systems (Erickson 2006; Schwab 2009). Extensive forests also have filtration benefits with respect to air quality. The U.S. Forest Service models air quality effects of forests in urban regions using a model 
called UFORE (Urban Forest Effects), which estimates the impacts of forest cover on removing particulates, $\mathrm{NO}_{2}, \mathrm{CO}_{2}$, $\mathrm{SO}_{2}$, and $\mathrm{CO}$ (Nowak and Crane 2000). Forests also play an important role in mitigating the urban heat island effect (Alberti et al. 2003). Finally, transitional forests may be extensive enough to play a measurable role in carbon sequestration at a global scale ("Box 1”).

Issues

The forest's ability to provide filtration and buffering systems have long been understood and their value reflected in a variety of management measures from shoreland zoning to local plumbing codes (Schwab 2009). These have all been directed at keeping human interference with forest ecosystem processes below thresholds where the services to humans are significantly degraded. However, the exact levels of carrying capacities, e.g. the optimal setback of structures from the shorelines of a lake or river or the optimal septic field size, are rarely known with precision. Instead, rough measures serve as approximations of carrying capacities making protection of these values too often a hit or miss proposition. The flood attenuation/ buffering values of forestlands can be often be maintained as a lowcost alternative to large-scale constructed solutions to managing floods and stormwater flows. However, pressure to convert forests to other land uses means significant efforts are required to maintain adequate forest land for these purposes 
(Colgan et al. 2013). The capacity of forests to provide air quality filtration benefits is significantly affected by the total amount of forest land, which in turn is affected by the development of multiple centers of high density residential and commercial/retail development typical of polycentric metropolitan regions. Over time the emergence of new centers away from the core city becomes the focal point for large-scale conversion of forested lands, making it extremely difficult to find the optimal balance between development and conservation. One ecosystem process, fire, can be a major threat to ever-increasing human habitation (Radeloff et al. 2005; Stein et al. 2009).

Amenity services

Values

Transitional forests are not separate from the urban area; they are an integral part. If forest cover is dominant it makes much of the rest of the metropolitan region feel quite rural in character, even if the entire region is chiefly inhabited by people who work in factories, offices, shopping outlets, or other urban settings. Forests are integral to the region's "sense of place” and can be seen as a key regional amenity in two senses. First, development is often attracted into forested areas, particularly for low to medium density residential development, not in spite of the fact that they 
are forested, but because they are forested (Tyrväinen 1997; Buyantuyev et al. 2010). People build houses in or near forests because it is often the lowest-cost land in the urban region and for some, they want to connect to the wooded landscape and/or they want to feel separate (if not isolated) from their neighbors. In other words, forests are one of the reasons that people come to the region and thus an element in sustaining economic success. Second, even for those people not living directly there, transitional forests and their associated natural elements, particularly water bodies, provide key recreational opportunities for people living throughout the urban region such as trails for walking, running, biking, skiing, and associated activities such as bird-watching. In this sense, transitional forests can become destinations, and are thus enjoyed by a wider population than those who are attracted to development amenities.

Issues

It is in the provision of these amenity values that the "natural" aspect of transitional landscapes is most apparent to people. This also makes perceptions of "naturalness" one of the most contentious features of the transitional landscape because it is much easier to perceive the change from a "green" rural landscape dominated by trees to a "gray" urban landscape dominated by buildings than to perceive changes in biodiversity and ecosystem function. Forest amenity values 
are further complicated because they are provided in both private and public contexts. For residents who own forests, this high-value amenity is out their back door and they are likely to act to maintain this. For others, the same amenities must be supplied collectively through public agencies or private entities like land trusts. This creates important opportunities for cooperation in enhancing values, but also generates conflicts such as when public trails border or run through private lands. It also raises difficult questions about the appropriate amount of public investment in forest recreational services to assure an equitable distribution of these services throughout the regional population.

\section{AN INTEGREATED APPROACH TO MANAGEMENT}

Optimizing all these values and coping with these diverse issues clearly requires integration among many players and considerations. Conceptually, the simplest solution that maximizes the values associated with these forests is to maintain all the existing forests and restore new forests in key sites. Various approaches can limit the loss of forest: public purchase of fee ownership and easements; tax incentives such as reduced property taxes (based on current use, not potential); land use controls or directed markets such as transferable development rights; maintaining a functioning forest products industry to provide land- owners an income from sale of timber or biofuels; providing forest management advice to 
landowners, planners, and others who influence land uses. How- ever, transitional forests are integral to urban areas, so simply halting development and forest conversion is not an option. In the end, some forest land will be lost in urban regions with expanding populations (Theo- bald 2005), and thus the key questions become: which forests should be a priority for conservation and how can human uses be managed to minimize adverse effects on forest values, including ecosystem integrity.

With respect to conservation, some forests are clear candidates; in particular, the special social, ecological, and hydrological values of riparian forests are well known (Lowrance et al. 1984; Naiman et al. 1993). Similarly, the importance of connectivity, both for dispersing biota and recreating people, suggests that the location of forests is a major consideration because some constitute critical landscape linkages. Some forests merit special consideration for one particular value: e.g. habitat for a rare plant, a major aquifer, a scenic vista, or an historic site. Whatever the rationale, from the perspective of a forest advocate, the first step in regional planning should be identifying those forests that are most important to conserve, and possibly to restore (e.g. planting trees in an abandoned farm field to reconnect a severed riparian corridor). Too often forest conservation is placed in a reactionary mode, responding to a proposal that would destroy or severely degrade a forest patch. Resisting all conversions of forest to alternative land covers and uses is rational only if the strategy is to preserve all forest and that argument will 
probably only prevail in heavily deforested areas. In most regions, a more realistic approach will recognize that only some forest will be maintained then focus on the question of which patches are most important to preserve for the suite of values delivered. Strategies focused on preserving high-value forest, while development activities proceed on lower value patches necessarily requires a proactive and regional approach. Studies to assess values delivered and prioritize conservation areas must be done proactively as they are often lengthy and cannot be completed in the timeframe of the land use permitting process (McCloskey et al. 2011). Additionally, studies are generally more credible if they are done independently of an effort to save any one patch (studies claiming the high value of one patch performed after it is threatened are often perceived suspiciously by some community members). Finally, planning processes need to be spatially explicit and regional in scale because of the important role of ecological connectivity as well as the strongly connected nature of roads and development (Meyer et al. 2012).

Protection of forest values in transitional forests need not be reduced to a simple binary choice of preservation versus development. Various approaches to management can be designed into public policies and private actions to limit degradation: e.g. forest practices restrictions, hunting regulations, culvert standards, development regulations such as subdivisions that incorporate open space, and trail systems designed to control the movements of hikers. At this 
level, one can find some conflicts between different approaches to foster particular values. For example, protecting habitat of sensitive species may mean limiting forest access, while enhancing recreational use generally means enhancing access to some degree. Such issues can become contentious, notably when motorized access is debated because it can facilitate deeper penetration into the forest, increases the risk of soil erosion, and (perhaps most importantly) because it often highlights conflicts between different recreational users. Finally, discussions about the threat of wildfire and the role of thinning and prescribed burning are particularly germane in transitional forests (Radeloff et al. 2005).

Whether the focus is on the broad issues of regional planning, or more focused on topics that surround minimizing forest degradation and conflicts between forest users, an integrated approach to managing these transitional forests will involve working with many parties. This process will be more complex than analogous undertakings in either urban forestry (where issues tend to be resolved one parcel at a time) or traditional forestry (where single private or government owners often control vast tracts) (Wu 2008).

If land fragmentation and conflicting goals about what roles the forest plays in the landscape are defining feature of the transitional forest, these are exacerbated by the institutional structures that must undertake the management efforts. Ownership resides with tens of thousands of landowners; planning and 
land use management are divided among municipal, county, state, and federal governments; within the different levels of government there are divisions among agencies; and within the private sector, there are private conservation and private development organizations. While there are region-wide organizations addressing forest concerns in some areas such as Portland, Oregon and the New Jersey Pine Barrens (Kline et al. 2004; Stein et al. 2005; Cotugno and Benner 2011; Stokes and Grogan 2011), the norm is highly fragmented planning and management systems that must develop collaborative strategies to address common issues related to the forest as a whole. This fragmentation of efforts increases the need to see the transitional forest as a whole system rather than simply the tree-covered parts of each individual jurisdiction.

Synthesis and future directions

Forests that fall in the transition between urban and remote settings are important for three fundamental reasons. First, as conceptualized here they constitute most of the forest area in many regions (e.g. northeastern and southeastern North America, much of Europe, and many parts of Asia, Africa, and South America). Second, because these forests are located where large numbers of people interact with forest land, many of the values they deliver are contingent on or enhanced by their proximity to people. Third, this same proximity to people places these forests under great threat of 
deforestation and degradation. Indeed a given tract of transition forest may well be more threatened by deforestation than a similar urban forest because the latter is likely to be recognized as a rare remnant in a landscape dominated by agriculture and development.

The challenge of managing transitional forests so that all of their values can be maintained and enhanced is substantial and will require new perspectives for both foresters and urbanists (Ball 1997). Unlike remote forests or urban parks where there is clear consensus on use, transitional forests occupy a zone of high uncertainty and high potential for conflict that requires a systematic approach to management within the fragmented ownerships and jurisdictions that characterize it. Such an approach should start by mapping transitional forests (Nowak et al. 1996) in order first to see them as forests rather than just the tree-covered parts of urban regional communities. In mapping forests, special attention should be paid to the explicit distribution of forest values and especially areas of highest and lowest conflict potential. The resulting picture should be projected ahead for periods of $5,10,20$, and 50 years so that the effects of drivers such as demographic, economic, technological, ecosystem, and climate change can be incorporated. Climate change offers a particular challenge for planning as explored in "Box 1".

Preparing future maps will involve a process of deliberative analysis that begins with the development or extension of planning support systems such as large- scale 
urban regional models, e.g. UrbanSim (Waddell 2002; Brail 2008), and then couples these socio- economic models with models of the forest region. These analytic tools must then be incorporated into multiple stakeholder involvement processes in which public agencies, nonprofit organizations, land owners, and businesses learn to see the transitional forest and their roles in it as well as how their interactions will shape the forest in years to come (Table 2). Research and management strategies that are effective, both in the sense of realistically addressing issues and receiving sufficient support to be implemented, will only emerge from this type of process (Knight et al. 2008).

Box 1: Adapting transitional forest management to climate change

An additional challenge to managing and maximizing services from transitional forests is the expected abrupt and large changes in climate. Transitional forests have two possible roles with respect to climate change: mitigation and adaptation.

Forests in general play a major role in possible climate mitigation. First a major benefit of retaining transitional forests could be their role as carbon-sinks. The US is currently a net carbon sink, primarily because of the large amounts of standing forest and rapid rates of reforestation (Pan et al. 2011). There is some possibility that urban forests could play a more important role than equivalent forests distant 
from cities because levels are typically substantially elevated by human activities in urban centers. This fertilization may increase standing biomass creating a negative feedback that can mitigate $\mathrm{CO} 2$ levels. Transitional forests could also play a role in generating biomass fuels, thus further mitigating total emissions. Finally, the short transportation distance from point of harvest for urban forest products to the point of consumption can reduce $\mathrm{CO}_{2}$ emissions.

Although mitigation remains an important planning objective for transitional forests, it is increasingly apparent that substantial levels of climate change will happen and planning for adaptation to this changed climate is increasingly important. Nearly all of the values provided by transitional forests discussed in the main article will need additional planning in the context of climate change to ensure that these values are still being maintained under future climate. For example, the growth curves and resulting sustainable yields of lumber, paper, and firewood will all change (often towards larger yields due to increased temperatures and $\mathrm{CO}_{2}$ fertilization, but they may also decline in some locations due to increased drought stress). In a changing climate, native species will likely shift their ranges hundreds of kilometers to track their optimal climates. This greatly increases the importance of having some native vegetation in human-dominated landscapes to facilitate these shifts. Human-assisted relocations into transitional forest patches may also become important although there are few guidelines on when or how to do this currently (Schwartz et al. 2012). 
Similarly, the role of forests in air and water quality will also change. Climate change means that some places will be wetter, some will be dryer, and some will be both in alternating periods. Managing forests for the current hydrologic regimes may be short- sighted, and it is not at all clear what the appropriate management strategies for a hydrological climate with significantly increased amplitudes in the wet/dry cycles would be. The evaporative cooling effects of forests that ameliorate heat-island effects in cities may become increasingly important, but this depends directly on adequate hydrological regimes to support these forests in hotter temperatures.

A major change in the forest landscape may result from changes in the patterns of human settlement in urban regions. Evidence exists that denser development is an effective means of lowering energy use and related emissions (Ewing et al. 2009). Denser development may reduce the total area of transitional forest conversion, but intensify the conversion in selected locations.

Although planning for and managing values derived from transitional forests is difficult enough in a relatively stable, present-day context it is imperative to also consider the role of these forests in a significantly changed future landscape. Otherwise, existing values derived from traditional forests could be lost in just a 
few generations.

\section{ACKNOWLEDGEMENTS}

This paper was completed with funding provided by the University of Maine, Sustainability Solutions Initiative (National Science Foundation ESPCoR \#EPS0904155) and Maine Agricultural and Forest Station Publication Number 3377. The authors would like to thank Spencer Meyer, David Kitteridge, Evan Richert, Mark Lapping, Lisa Schulte and two anonymous reviewers for helpful feedback that improved earlier drafts.

\section{REFERENCES}

Alberti M, Marzluff J, Shulenberger E, Bradley G, Ryan C, Zumbrunnen C (2003) Integrating humans into ecology: opportunities and challenges for urban ecology. BioSci- ence 53:1169-1179

Alderman D (2013) North American and global forest product markets. Timber measurement society central meeting. Ferndale, WA, 10-12 April

Athreya V, Odden M, Linnell JDC, Krishnaswamy J, Karanth U (2013) Big cats in our backyards: persistence of large carnivores in a human dominated landscape in 
India. PLoS ONE 8:e57872

Ball J (1997) On the urban edge: a new and enhanced role for foresters. J For 95:610

Beattie J, Kollin C, Moll C (2000) Trees tackle clean water regulations. Am For 106:18-19

Brail RK (2008) Planning support systems for cities and regions. Lincoln Institute of Land Policy, Cambridge 312

Butler BJ, Ma Z, Kittredge DB, Catanzaro PF (2010) Social versus biophysical availability of wood in the northern United States. North J Appl For 27:151-159

Buyantuyev A, Wu J, Gries C (2010) Multiscale analysis of the urbanization pattern of the Phoenix metropolitan landscape of USA: time, space, and thematic resolution. Landsc Urban Plan 94:206-217

Colgan C, Yakovleff D, Merrill S (2013) An assessment of the economics of natural and built infrastructure for water resources in Maine. University of Southern Maine, New England Environmental Finance Center, Portland, ME p 58 
Cotugno A, Benner R (2011) Regional growth management in Portland metropolitan area. In: Montgomery CK (ed) Regional planning for a sustainable America: How creative programs are promoting prosperity and saving the environment. Rutgers University, Piscataway, pp 35-47

D’Amato AW, Catanzaro PF, Damery DT, Kittredge DB, Ferrare KA (2010) Are family forest owners facing a future in which forest management is not enough? North J Appl For 108:32-38

Degraaf, RM, Healy, WM (1990) Is forest fragmentation a management issue in the Northeast? Gen Tec Rep NE-140. US Forest Service, Northeastern Forest Experiment Station. Radnor, PA p 32

Edwards KK, Bliss JC (2003) It's a neighborhood now: practicing forestry at the urban fringe. J For 101:6-11

Egan AF, Luloff AE (2000) The exurbanization of America's forest: research in rural social science. J For 98:26-30

Erickson D (2006) MetroGreen: connecting open space in North American cities. 
Island Press, Washington 352

Ewing R, Bartholomew K, Winkelmn S, Walters J, Chen D (2009) Growing cooler: the evidence of urban development and climate change. Renew Resour J 25:6-13

Fischer AP, Bliss J, Ingemarson F, Lidestavd G (2010) From the small woodland problem to ecosocial systems: the evolu- tion of social research on small-scale forestry in Sweden and the USA. Scand J For Res 25:390-398

Gibbs JP (1998) Distribution of woodland amphibians along a forest fragmentation gradient. Landscape Ecol 13:263-268

Godefroid S, Koedam N (2007) Urban plant species patterns are highly driven by density and function of built-up areas. Land Ecol 22:1227-1239

Gordon JC, Sampson RN, Berry JK (2004) The challenge of maintaining working forests in the wildland-urban inter- face. In: Vince SW, Duryea ML, Macie EA, Hermansen A (eds) Forests at the wildland-urban interface: conservation and management. CRC Press, Boca Raton, pp 15-23

Hansen AJ, Knight RL, Marzluff JM, Powell S, Brown K, Gude PH, Jones K 
(2005) Effects of exurban development on biodiversity: patterns, mechanisms, and research needs. Ecol Appl 15:1893-1905

Kline JD, Azuma DL, Alig RJ (2004) Population growth, urban expansion, and private forests in Oregon. For Sci 50:22-43

Knight AT, Cowling RM, Rouget M, Balmford A, Lombard AT, Campbell BM (2008) Knowing but not doing: selecting priority conservation areas and the research-implementation gap. Conserv Biol 22:610-617

Lindenmayer DB, Fischer J (2003) Sound science or social hooks: a response to Brooker's application of the focal species approach. Landsc Urban Plan 62:149158

Lowrance R, Todd R, Fail J, Henderickson O, Leonard R, Asmussen L (1984) Riparian forests as nutrient filters in agricultural watersheds. BioScience 34:374377

Maine Revenue Service (2013) Maine tree growth tax law. Property tax bulletin 19. State of Maine Department of Administrative and Financial Services. Augusta, ME 
Martin LJ, Blossey B, Ellis E (2012) Mapping where ecologists work: biases in the global distribution of terrestrial ecological observations. Front Ecol Environ 10:195-201

McCloskey JT, Lilieholm RJ, Cronan CS (2011) Using Bayesian belief networks to identify future compatibilities and conflicts between development and landscape conservation. Landsc Urban Plan 101:190-203

McWilliam W, Brown R, Eagles P, Seasons M (2014) Barriers to the effective planning and management of residential encroachment within urban forest edges: a Southern Ontario, Canada case study. Urban For Urban Green 13:48-62

Medley KE, McDonnell MJ, Pickett STA (1995) Forest-land- scape structure along an urban-to-rural gradient. Prof Ge- ogr 47:159-168

Meyer SR, Johnson ML, Lilieholm RJ (2012) Land conservation in the United States: evolution and innovation cross the urban-rural interface. In: Laband DN, Lockaby BG, Zipperer W (eds) Urban-rural interfaces: linking people and nature. American Society of Agronomy, Madison, pp 225-255 
Naiman RJ, Decamps H, Pollock M (1993) The role of riparian corridors in maintaining regional biodiversity. Ecol Appl 3:209-212

Neuschulz EL, Brown M, Farwig N (2013) Frequent bird movements across a highly fragmented landscape: the role of species traits and forest matrix. Anim Conserv 16:170-179

Nowak DJ, Crane DE (2000) The Urban Forest Effects (UFORE) model: Quantifying urban forest structure and functions. In: Hansen M, Burk T (eds) Integrated tools for natural resources inventories in the 21st century. Gen Tech Rep NC-212. US Department of Agriculture, Forest Ser- vice, North Central Forest Experiment Station, St Paul, MN pp 714-720

Nowak DJ, Rowntree RA, McPherson EG, Sisinni SM, Kerkmann ER, Stevens JC (1996) Measuring and analyzing urban tree cover. Landsc Urban Plan 36:49-57

Pan Y, Birdsey RA, Fang J, Houghton R, Kauppi PE, Kurz WA, Phillips OL, Shvidenko A, Lewis SL, Canadell JG, Ciais P, Jackson RB, Pacala SW, McGuire AD, Piao S, Rautiainen A, Sitch S, Hayes D (2011) A large and persistent carbon sink in the world's forests. Science 333:988-993

Patterson ME, Montag JM, Williams DR (2000) The urbanization of wildlife 
management: social science, conflict, and decision-making. Urban For Urban Green 1:171-183

Radeloff V, Hammer RB, Stewart SI, Fried JS, Holocomb SS, McKeefry JF (2005) The wildland-urban interface in the United States. Ecol Appl 15:799-805

Schwab JC (ed) (2009) Planning the urban forest: ecology, economy, and community development. Planning Advi- sory Service Report 555. American Planning Association. Chicago, IL p 156

Schwartz MW, Hellmann JJ, Mclachlan JM, Sax DF, Borevitz JO, Brennan J, Camacho AE, Ceballos G, Clark JR, Doremus H, Early R, Etterson JR, Fielder D, Gill JL, Gonzalez P, Green N, Hannah L, Jamieson DW, Javeline D, Minteer BA, Odenbaugh J, Polasky S, Richardson DM, Root TL, Safford HD, Sala O, Schneider SH, Thompson AR, Williams JW, Vellend M, Vitt P, Zellmer S (2012) Managed relocation: integrating the scientific, regulatory, and ethical challenges. BioScience 62:732-743

Shelby B, Tokarczyk JA, Johnson RL (2004) Timber harvests and forest neighbors: the Urban Fringe Research Project at Oregon State University. J For 102:8-13 
Soulé ME (1991) Land use planning and wildlife maintenance: guidelines for conserving wildlife in an urban landscape. J Am Plan Assoc 57:313-323

Stein SM, McRoberts RE, Alig RJ, Nelson MD, Theobald DM, Eley M, Dechter M, Carr M (2005) Forests on the edge: housing development on America's private forests. Gen Tech Rep PNW-GTR-636. US Forest Service, Portland, OR p 15

Stein SM, McRoberts RE, Alig RJ, Carr M (2009) Forests on the edge. In: Smith WB, Miles PD, Perry CH, Pugh SA (eds) Forest resources of the United States, 2007. US Forest Service, Washington, pp 36-40

Stokes JC, Grogan SR (2011) Pinelands National Reserve: saving a unique ecosystem in the nation's most densely developed state. In: Montgomery CK (ed) Regional planning for a sustainable America: how creative programs are promoting prosperity and saving the environment. Rutgers University, Piscataway, pp 83-90

Theobald DM (2005) Landscape patterns of exurban growth in the USA from 1980 to 2020. Ecol Soc 10:32

Thorne S, Sundquist D (2001) New Hampshire's vanishing forests: conversion, fragmentation and parcelization of forests in the Granite State. Society for the 
Protection of New Hampshire Forests, Concord 153

Tilghman NG (1987) Characteristics of urban woodlands affecting breeding bird diversity and abundance. Landsc Urban Plan 14:481-495

Tyrväinen L (1997) The amenity value of the urban forest: an application of the hedonic pricing method. Landsc Urban Plan 37:3-4

Waddell P (2002) UrbanSim: modeling urban development for land use, transportation and environmental planning. J Am Plan Assoc 68:297-314

Wear DN, Liu R, Foreman JM, Sheffield RM (1999) The effects of population growth on timber management and inventories in Virginia. For Ecol Manage 118:107-115

Wu J (2008) Toward a landscape ecology of cities: beyond buildings, trees, and urban forests. In: CarreiroMargaret M, Song Y-C, Wu J (eds) Ecology, planning, and management of urban forests. Springer, New York, pp 10-28

Zipperer WC, Foresman TW, Walker SP, Daniel CT (2012) Ecological consequences of fragmentation and deforestation in an urban landscape: a case study. Urban Ecosystems 15:533-544 
Fig. 1 Differing definitions of transitional forests in four geographic areas. Blue lines show borders of US census Metropolitan Statistical Area (MSA) regions (with solid blue insets identifying census urban regions). Background is color coded. White indicates houses $\backslash 1$ house km-2 OR forest cover less than $50 \%$. Black indicates urban housing densities ([100 houses km-2). Two shades of gray are intermediate (1-10 houses km-2 and darker gray for 10-100 houses km-2) with at least 50 \% forest cover. Housing densities from CEISIN rasterization of US Census 2010 at $1 \mathrm{~km}$ resolution pixels. Forest data from NLCD 2001 (summarized to $1 \mathrm{~km}$ and then interpolated to the NLCD grid). MSA and Urban areas from US Census
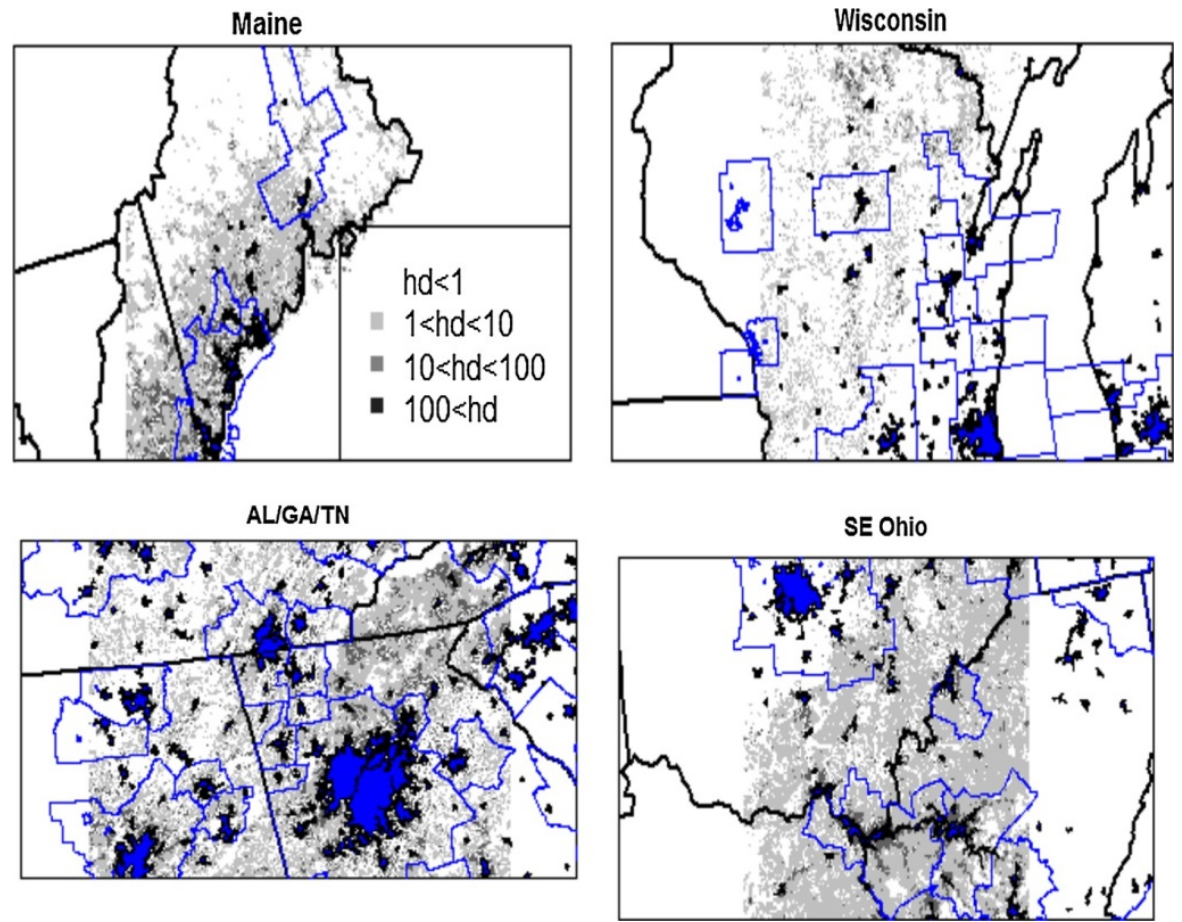
Fig. 2 Graphical depiction of actual and potential interest of urbanists and foresters as a function of distance from urban centers and remote forests. Foresters often see “their” forest including only human densities where harvesting can occur and conservationists focus on forests with low densities that limit human impacts. Meanwhile, urbanists likely see the end of the urban domain at "low" densities of one dwelling unit per ha, which a forester would see as a very high density. Thus, neither set of disciplines claims the middle in a quantitative sense
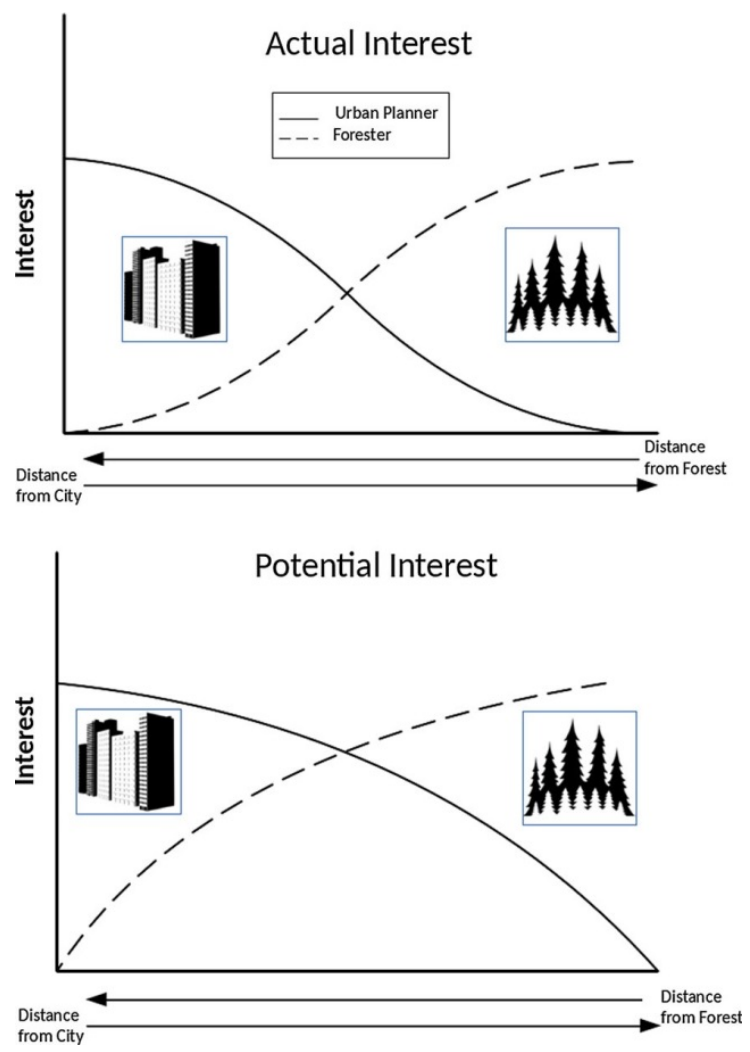
Table 1 Values, primary issues, and management recommendations for the various attributes of transitional forests

\begin{tabular}{|c|c|c|c|}
\hline Attribute & Value & Issue & $\begin{array}{l}\text { Management } \\
\text { Recommendations }\end{array}$ \\
\hline Forest products & $\begin{array}{l}\text { Renewable materials and } \\
\text { fuels for society } \\
\text { Income for landowners }\end{array}$ & $\begin{array}{l}\text { Limited and changing } \\
\text { markets } \\
\text { Minimum area needed for } \\
\text { financial viability } \\
\text { Policy restrictions } \\
\text { Active Management and } \\
\text { specialized knowledge } \\
\text { required } \\
\text { Hard to quantify and } \\
\text { project }\end{array}$ & $\begin{array}{l}\text { Maintain and expand landowner } \\
\text { assistance programs } \\
\text { Provide financial incentives } \\
\text { (e.g. tree tax laws) } \\
\text { Promote large blocks of } \\
\text { working forests } \\
\text { Protect against land use } \\
\text { intrusions that conflict with } \\
\text { rural production }\end{array}$ \\
\hline Biodiversity & $\begin{array}{l}\text { Habitat for most native } \\
\text { species } \\
\text { Significant populations for } \\
\text { many species } \\
\text { High primary productivity } \\
\text { Connectivity }\end{array}$ & $\begin{array}{l}\text { May be population sinks } \\
\text { for some species and } \\
\text { sources for others } \\
\text { Impacts of invasive } \\
\text { species, overexploitation, } \\
\text { \& contaminants }\end{array}$ & $\begin{array}{l}\text { Maintain and restore } \\
\text { connectivity } \\
\text { Protect key forests, especially } \\
\text { large blocks and riparian areas } \\
\text { Manage access } \\
\text { Develop and enforce laws } \\
\text { limiting impact }\end{array}$ \\
\hline Ecosystem functions & $\begin{array}{l}\text { Water supply } \\
\text { Filtration/buffering to } \\
\text { reduce impacts on } \\
\text { hydrologic systems } \\
\text { Flood control } \\
\text { Filtering of air pollutants }\end{array}$ & $\begin{array}{l}\text { Location of forestland } \\
\text { relative to sensitive } \\
\text { hydrologic features } \\
\text { Threshold levels of } \\
\text { adequate forest } \\
\text { Amount of undeveloped } \\
\text { land available for flood } \\
\text { attenuation and water } \\
\text { quality maintenance } \\
\text { Amount of forest land in } \\
\text { urban core and emerging } \\
\text { centers }\end{array}$ & $\begin{array}{l}\text { Choose between (a) maximum } \\
\text { acceptable loss, (b) no net loss } \\
\text { (c) minimum acceptable gain } \\
\text { Identify highest value areas for } \\
\text { filtration/buffering } \\
\text { Choose appropriate policy tools } \\
\text { from among regulatory, } \\
\text { taxation, and quasi-market tools } \\
\text { such as transferable } \\
\text { development rights }\end{array}$ \\
\hline Amenity services & $\begin{array}{l}\text { Regional "sense of place" } \\
\text { Outdoor recreation both } \\
\text { privately and publicly } \\
\text { provided } \\
\text { Attractive for low density } \\
\text { residential development } \\
\text { because of land costs and } \\
\text { other amenity values }\end{array}$ & $\begin{array}{l}\text { Highly visible value lead to } \\
\text { highly visible conflicts } \\
\text { Finding the equitable } \\
\text { balance between private } \\
\text { and public provision of } \\
\text { amenities } \\
\text { Economic value of } \\
\text { developed land alters } \\
\text { economic considerations of } \\
\text { other forest uses }\end{array}$ & $\begin{array}{l}\text { Anticipate and reduce the } \\
\text { potential for conflicts within } \\
\text { and between amenity users } \\
\text { Assure amenities are provided } \\
\text { for diverse income groups, age, } \\
\text { and ethnic groups } \\
\text { Develop tax policies to favor } \\
\text { certain land uses such as current } \\
\text { use property tax assessments }\end{array}$ \\
\hline
\end{tabular}


Table 2 Key research topics on transitional forests along a continuum of temporal scale and nature of research

Short-term and applied

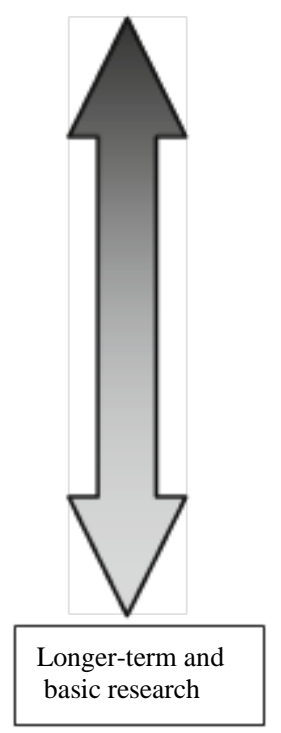

Clearly define transitional forests for comparative study among researchers

Develop and maintain maps of transitional forests including forest attributes such as age, density, species, etc. (not just a broad land use type within other urban maps)

Assess condition and composition of transitional forests and their likely future growth/succession trajectories

Communicate and initiate stakeholder processes based on forest value

Explicitly map forest values

Assess potential conflicts, especially in transitional forest patches with pivotal roles in delivering values

Explore routes to integrate values delivered by transitional forest into decisionmaking processes

Develop projections of forces and threats to transitional forests

Develop and enhance region-wide planning processes to examine transitional forests in regional context

Identify how polycentric institutions can simultaneously pursue regional planning while incentivizing local behavior that integrates with regional plans

Study effects of fragmentation and effects of low density development on organisms living in transitional forests

Improve understanding of responses to climate change in transitional forests

Understand economic mechanisms that control highest and best use within transitional forests

Because of the inherently interdisciplinary and multi-scaled nature of the challenges of managing transitional forests, no question is purely applied or purely basicresearch 